\title{
Special Contribution by Dr. Mustafa AYDIN, EURAS President of Board of Trustees, Istanbul Aydin University
}

\author{
Ibn Hani al-Andalusi ${ }^{1}$
}

\begin{abstract}
This research is one of the historical literary studies as it dealt with the life of the poet Ibn Hani Al-Andalus. This study came in two sections. The first one is devoted to Ibn Hani's life, especially in the scientific and literary realms. Further, this research can be considered as a modern study and interpretation on his personality that influences his art. In the second section, the main concern is to talk about technical characteristics and poetic references in Ibn Hani Al-Andalusi's poetry. Then, I illustrate the most important explanations that dealt with his collection of poems (diwan). In the last part, the research draws several conclusions. The most important of which was an explanation of the literary reputation of Ibn Hani, especially in his life-time, and the position of the Fatimid caliph vis-à-vis Ibn Hani. Finally, as the research demonstrated, Ibn Hani was one of those who represented a new trend in the characteristics of poetry.
\end{abstract}

Key words: Ibn Hani, Al-Andalus, Andalusian literature, the Fatimids, the Fatimid state, Arabic literature. 


\section{INTRODUCTION}

Poetry has a great importance, especially during the time of the prophecy, and it was closely linked to the daily concerns of people. If poets grew up in a tribe, they played major roles in the weddings or in different ceremonies. Poetry was also a means of defense for religion and religious figures, such as the Prophet. After the era of prophecy, poetry was used for political purposes as happened in the Umayyad era. Then, its purposes expanded to include all components of society: social, cultural, political, religious, natural and literary life. In other words, poetry has become an image of society and an expression of reality, which makes the study of poetry so important There were also two significant reasons that emphasize its importance in relation to historical literary studies:

- The study of poetry revives the literary heritage, which is part of the history of world culture.

- The study of poetry reveals the stages of linguistic development in which poetry is the main subject.

From that points and in view of the literary and historical importance that characterized the Andalusian poet Ibn Hani, I studied his book, through the context of his life, the characteristics of his poetry, and the most important poetic purposes in his office using the historical and analytical methods. This research contained an introduction with two sections: the first topic included two sub-topics, and the second topic included sub-three topics, and the research shows its findings in the form of statements and recommendations. 


\section{The first section: Features of the era of Ibn Hani.}

\section{The first topic: his age and his life.}

\section{First: the political situation in the era of Ibn Hani.}

We cannot understand the poetry of Ibn Hani unless we understand the era in which he was living, and get acquainted with the most important political, scientific and cultural events that prevailed in his time, especially what had an impact on his poetry, that his poetry was dominated by political tendency, because of his proximity to power. At that time, especially from the Fatimid Caliph Al-Muizz Ldin Allah. At the beginning of the fourth century $\mathrm{AH}$, and after the establishment of the Umayyad state in Andalusia in $317 \mathrm{AH}$, there were three countries sharing the Islamic world: the Abbasid state in Baghdad, the Umayyad state in Cordoba, and the Fatimid state in Africa.

As for the Abbasid caliphate, disintegration and weakness were running in its parts, as it was suffering from many strife and turmoil, corruption of state affairs, loss of the caliphate's prestige, and other matters that were gradually dragging it towards its demise, as a result of its weakness in carrying out the country's politics and managing its affairs, which led To corrupt laws, disorder, and tyranny of ministers, princes and leaders, who removed the obedience of the caliphs. Therefore, the greedy or hostile forces began to move and agglomerate to separate from the body of this state and establish mini-states for themselves far from the authority of Baghdad, as this was done, and the state was transformed into multiple states in the hands of the Arab leaders and princes and others. The Qarmatians seized Syria and part of the Arabian Peninsula, as well as the 
Samanids seized the land of Khurasan, the Hamdanids over Mesopotamia and Diyarbakir, and the Banu Buaih over Persia, leaving only Baghdad and Egypt for the Abbasids.

Thus, the eastern provinces began to separate from the Abbasid caliphate, while the rest of the possessions gradually became independent from the central caliphate. These events coincided with a great Shiite expansion in the fourth century $\mathrm{AH}$, which made the Abbasid caliphate lose its prestige and control. The Zaydis succeeded in establishing a ruling state in Tabaristan in $250 \mathrm{AH}$, and in Yemen in $284 \mathrm{AH}$, and the Qarmatians seized southern Iraq, Bahrain and Al-Ahsa. Thirty years had passed since the victory of the Fatimids, but the collapse of the authority of the Abbasid caliphate was evident when the Buyids succeeded in imposing their control over Baghdad, the center of the Abbasid Caliphate. Further, sectarian strife and religious unrest increased between the followers of the Sunni and Shiite doctrines.

On the other hand, the Christian Byzantine state in Constantinople was lying in wait for the Abbasid Caliphate, waiting for opportunities to take advantage of this division that afflicted it, and in the meantime Egypt struggled with the worst conditions of weakness, turmoil, chaos and high prices. As a result of that, the Fatimids in Africa exploited the conditions in Egypt that were their focus, so they sent their calls Many people gathered around them, until it was said that camphor al-Ikhshidi entered their call, and their successors tried to conquer Egypt, but they were not able. 
When camphor Al-Ikhshidi, the owner of Egypt, died, hearts differed in it, and strife arose, and great expense occurred. Them, Al-Muizz Li Din Allah the Fatimid took advantage of the opportunity to achieve the goal of the Fatimids, and he ordered the preparation of an army that he made Jawhar al-Saqali as its leader, and he directed it to Egypt, went out by himself to bid him farewell, stayed for days in his camp, and he used to go out to Jawahar of every day and be alone with him. Then, he went out to him one day. Jawhar stood in his hands And the army met, so Al-Muizz turned to the sheikhs whom he directed with Jawhar, and said: "if Jawhar had left this alone to conquer Egypt, then you would enter Egypt without war, and descend into the ruins of Ibn Tulun, and a city called Cairo would be built that would defeat the world."

Ibn Hani was not far from these events, as he described Al-Muizz 's army that went out wanting Egypt by saying:

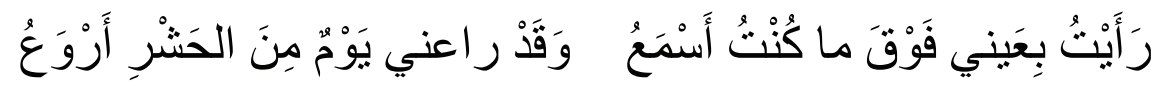

And when Jawhar al-Saqali entered the city of Alexandria, its people surrendered without a fight, and when he decided to go to the city of Fustat, the Ikhshidid soldiers fled from the city. Then, he sent its people a messenger with a desire for reconciliation. The Messenger was called Abu Ja far Muslim Ibn Ubayd Allah, and he was one of the Fatimids hoping to find a place with Jawhar, so Jawhar received him and honored him with the best honor, and Ibn Hani referred to Muslim by saying:

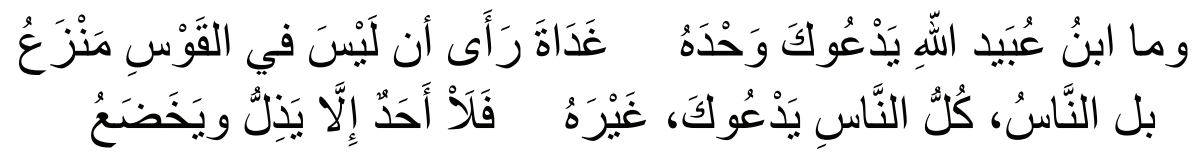


Then Jawhar entered Egypt in the middle of Shaban $358 \mathrm{AH}$ and sermoned in the Al-Ateeq Mosque in the name of Al-Muizz, and the Alawite da'wa was established, and to this event Ibn Hani pointed out in a poem that begins:
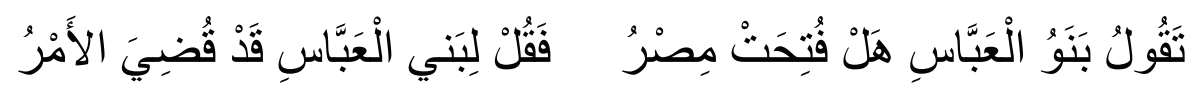

\section{Second: the scientific and literary situation in the era of Ibn Hani.}

Iraq, the Abbasid state: despite the weakness and turmoil that the Abbasid caliphate was suffering from, and despite the disintegration that took place within it, the princes of these states were interested in the Arabic language, and they had participated in the scientific and literary councils.

Al-Buaihi state had a keen interest in literature, and he brought a number of poets like Al-Mutanabbi, and he also relied on a great writer, Abu AlFadl Muhammad Bin Al-Hussein, known as Ibn Al-Ameed. Al-Thaalabi said about him: "it is the only era in writing, ... called Al-Jahiz the last, ... proverbial in rhetoric, and it ends in indicating eloquence and ingenuity, just as the supporter of the state Al-Buihi took from Al-Sahib bin Abbad, the poet, the writer, as a minister."

A number of the Seljuk ministers were also known for the love of scholars and writers, such as the regime of King Abu Ali al-Hasan bin Ali, according to Abu Shama al-Maqdisi: he was a jurist scholar, and he was the closest of people to him and the scholars dearest to him, and he used to debate with them in forums, and search for mysterious issues. 
And the poet Abu Ismail Al-Hussein bin Ali Al-Tughrai, who was a minister to Sultan Masoud bin Muhammad Al-Seljuki, was famous during the era of the Seljuks.

Literature and science rose to prominence in the Hamdanid Emirate / 317 AH - 394 AH / which took control of Mosul, Diyar Bakr, Aleppo, Homs, Hama, Antioch, Manbij, and Maarat al-Nu'man, until the court of Saif alDawla in Aleppo gathered a group of writers and poets, such as Abu alTayyib al-Mutanabi, Abu Firas al-Hamdani and Ibn Nabatat al-Saadi. And Abi Al-Faraj Al-Asfahani and others.

And in Egypt and the Sham, the state of the Ikhshidids was established / $323 \mathrm{AH}-358 \mathrm{AH} /$ and a number of poets and writers appeared in it, the most prominent of whom were Ibn Tabataba, Ibrahim al-Jizi - the writer of Kafour -, Saleh bin Mu'nis, and al-Hasan bin Ali al-Asadi.

When the Fatimid state ruled Egypt and the Levant / $358 \mathrm{AH}-566 \mathrm{AH} /$, the sciences and literature enjoyed great care during its reign, and a number of its kings excelled with poetry systems such as the Almuizz. Further, the poets who had contact with them received the high positions, Sunni gifts and generous gifts of princes and kings.

The Arab Maghreb The Fatimid State: The Fatimid era in the Arab Maghreb witnessed a kind of literary boom, especially the prose literature that was popular in that era, and it was predominantly preaching and wills. The impetus for the emergence of this type of literary expression was what the Fatimids described as preachers For the Shiite doctrine, which is contrary to what the majority of the population was, which requires the 
presence of preachers with high literary skill and expressive power through which they can communicate their call to others in a sober manner with clear words and brief words.

The first caliph Ubayd Allah Al-Mahdi / 296 AH - 322 AH / was also famous with the abundance of official correspondence that he exchanged with his crown prince, Abi al-Qasim, who was in charge of some conquests in Morocco. These correspondences were characterized by the durability of the style, the sobriety of the phrase, the keenness to use the rhetorical innovations, the mastery in the use of interceptive sentences and expressions that contain glorification of the caliph. Further, the ability to frequent martyrdom from the Holy Qur'an and the noble Hadiths.

During the reign of Caliph Al-Muizz Li Din Allah / 341 AH - 362 AH / Prose literature flourished in the field of administration and correspondence, and among the most prominent factors of its prosperity was the exchange of messages between the caliph and his commanders and men on the one hand, and between the caliph and those who revolted against him on the other hand.

Among the prose literature of the Fatimid era in the Arab Maghreb, the political and sectarian sermons that the caliphs used to deliver on religious and other occasions.

These sermons were distinguished by the durability of the style, the sweetness of words, the power of influence, and the frequent quotes from the Holy Qur'an. 
The Fatimid era in Maghreb was also unique as a type of prose literature, which was known as the signatures that the Fatimid caliphs were passionate about, and it is an attractive type of literary expression that is summarized in what the caliph comments on the books and letters brought to it, and these signatures are characterized by the combination of shortness and brevity.

As for poetry, they employed it in the service of their doctrine, spreading their beliefs, defending them, and praising and praising the caliphs.

Cordoba, the state of Andalusia: Andalusia witnessed in the era of Ibn Hani a wide prosperity in various types of sciences, whether Islamic or Arabic, because when the Arab conquerors entered Andalusia they carried with them all the colors of culture, science and thought. On the other hand, the people of Andalusia began to migrate In the East, and they transfer their knowledge to their countries, and they brought with them some literary figures influencing literary, scientific and artistic life, such as Ziryab, a student of the Al-Mawsili. Further, Abu Ali al-Qali al-Baghdadi, and a number of writers grew up, until Andalusia became a destination for those aspiring to glory and money from the people of knowledge and commerce.

Al-Maqri, the owner of Al-Tayyib, says: "all sciences have luck and care - with the people of Andalusia - except for philosophy and astrology, for they have great luck in their private people, and they do not pretend to know them, because the fearful of the public, for whoever it is said he reads philosophy or works in astrology, the public has called him a heretic, and his breath is restricted to him, and if he falls into suspicion, they pelted 
him with stones or burned him before his command reaches the Sultan, or the Sultan kills him closer to the hearts of the public, and their kings often instructs their kings to burn the books of this matter if they are found."

Andalusia reached its apogee in the days of Abd al-Rahman al-Nasir / $300 \mathrm{AH}-350 \mathrm{AH} /$ and his great library, which he established under the supervision of his Crown Prince Al-Hakam Al-Mustansir, was famous until Ibn Khaldun said: "for his reign, there were treasuries of books that were not for anyone before him or after him."

A number of poets and writers have emerged in this era, such as Ibn Abd Rabbo / $246 \mathrm{AH}-328 \mathrm{AH} /$ who is considered one of the most famous poets of the stage in the history of Andalusian literature, the owner of the unique contract which is considered one of the most important sources of Arabic literature, and among those who emerged in this era is our poet Ibn Hani, who contacted the owner of Seville And he gained a prestigious position with him. However, he was carried to immigration from Andalusia, so he went out to North Africa.

\section{The second topic: introducing Ibn Hani:}

First: his name, lineage, title and surname.

Muhammad bin Hani bin Muhammad bin Saadoun al-Azdi, Abu alQasim. Ibn al-Ahdal said: "the nickname of Ibn Hani Abu Nawas is the noun of al-Hasan bin Hani al-Hakami al-Iraqi, his lineage goes back to the Umayyad leader Muhallab ibn Abi Safra al-Azdi, nicknamed the 'Western Mutanabi', because he was one of the most famous poets of the Maghreb 
at all, and he was with them like Al-Mutanabi in the East, and he was contemporary to his time."

Ibn Khallikan said: "there is no one among the Moroccans who is in his class, neither among their earlier nor among their backward ones, but rather he is their most prominent at all, and he is with them like the Mutanabbi in the East, and they were contemporaries."

\section{Second: His birth, upbringing and death.}

The poet Ibn Hani was born in the village of Sukoun in $320 \mathrm{AH}$, one of the Seville Andalusian villages, and he grew up with it and learned poetry and literature with it, just as he lived in the bosom of a family of lineage, knowledge and literature, and his father "Hani" was from a village in Mahdia in Africa. He was a literary poet, and he moved to Andalusia. He had a good fortune from literature and poetry, he preserved the poems and news of the Arabs, and contacted the owner of Seville and gained favor with him. He was consuming much pleasure, and he was accused of embracing the doctrine of philosophers, which made the people of Seville take revenge on him, the talks misrepresented the rights of the king because of him, and he was also accused of his doctrine as well. The, the king advised him to be absent from the country for a period in which his news would be forgotten, so he separated from her and was twenty-seven years old on that day.

He went out traveling in the country, and arrived in Maghreb, where he met Jawhar the leader and praised him, then he went to the Zab and contacted Jaafar, the son of Andalusia, and his brother Yahya. After that, he returned to their door and embraced them, so they honored him and 
benefited him and was kind to him. The news of Al-Muizz reached Abu Tamim, so he brought him and he was better and honored, and when he left the Egyptian lands, he asked his permission to return to his children to bring them and join him, so he authorized him and he left him, when he reached Barqa. Then, he went down to one of its notables to rest for several days, and he went out for a drunk night from his house, when people came to find him thrown in a corner of the country, suffocated. The cause of this and its perpetrator were not known, and his death was likewise on Wednesday in the year sixty-two and three hundred, and he was over forty, and when Al-Muizz reached the news of his death, he regretted it with great regret and said: "this is what we had hoped to be proud of the poets of the East, we were not destined for that."

Al-Zarkali mentioned that he deported to Africa and Algeria, then contacted the Fatimid Caliph Al-Muizz Li Din Allah Al-Ubaidi Maad bin Ismail, and he landed with him in Mansouriya near Kairouan, and stayed for a short period, after which Al-Muizz left to Egypt, after his leader, Jawhar al- Saqali, opened it. Ibn Hani joined him and returned to Seville and took his children and went to Egypt, later with Al-Muizz, when he arrived in Barqa, he was killed in it.

Ibn Khallikan mentioned that when Al-Muizz went to the Egyptian lands, Ibn Hani's funeral with him, and he returned to Al-Maghreb to take his children and join him, so he prepared and followed him. When he arrived in Barqa, someone from its family added him, and he stayed with him for days in the council of people, and it is said that they ravaged over him and killed him, and it was said: "he went out from that house while he was 
drunk, he slept on the road and became dead, and the cause of his death was not known, and that was early on Wednesday for seven nights from Rajab in the year sixty-two and three hundred, he was thirty-six years old, and it was said forty-two."

When the news of the poet's death reached the Fatimid caliph al-Mu'izz Li Din Allah on his way to Egypt, he showed his sorrow for his death and his admiration for his poetry, when he said: "this man - meaning Ibn Hani - we were hoping to be proud of the poets of the East, but he was not able to us."

\section{The second section: poetic characteristics in Ibn Hani's poetry:}

The first topic: the technical characteristics in the poetry of Ibn Hani. The first thing that the researcher notices in the era of Ibn Hani is the emergence of a new poetic trend that revived the original Arab poetic characteristics that were abandoned by the owners of the modern trend led by Abu Nawas. Arabic poetry lost many of its simple and naive Bedouin characteristics, so this trend came to restore Arabic poetry its ancient artistic characteristics. On the one hand, and to limit that revolution that rebelled against Arabic poetry at the hands of those modern poets on the other hand.

This new trend was conservative on the one hand, and again on the other hand, as it preserved the poetic method of the poem in terms of language and music, but it is considered as renewing in the meanings and images of poetry. 
In terms of the approach, the owners of this trend followed the old poets' habit, starting with weeping over the ruins or opening with preliminary spinning, and then moving on to the poet's main purpose.

As for the language, they prefer the tendency to eloquence and grandeur of the phrase, over the habit of poets in the past, and as for poetic music, they influence long weights with a solemn tone, and strong rhymes with resonant resonance.

As for the spirit and ethics of Arabic poetry, the proponents of this trend tend to be far away from the extremism and rebellion that characterized the Abu Nawas trend, which was mocking traditions and the people's modesty, as well as being far from excessive immorality, public disobedience and bragging about committing evil.

As for the meanings and images, they were immersed in meanings and images, searching for the wonderful innovator, the funny absent, or the distant stray, and this trend reached its peak at the hand of Al-Mutanabi, as he is considered the pioneer of this direction.

One of the most important characteristics that characterized Ibn Hani's poetry was his ability to control speech. As he was clutching his tongue, he distracted him as he wanted, so his poetry was characterized by the graphic and expressive power that he used in the service of the Fatimid caliphs, by spreading their beliefs, calling to embrace them, praising their successors and praising them and spreading their virtues, including his praise of the Fatimid caliph Al-Muizz Li Din Allah, he praised him in several poems, including his Nuniyya poem, which is considered one of 
the deceitful praises and elites of poetry, and it is the first thing he sang in Kairouan, and Al-Muizz gave him a precious prize, he says in its beginning:

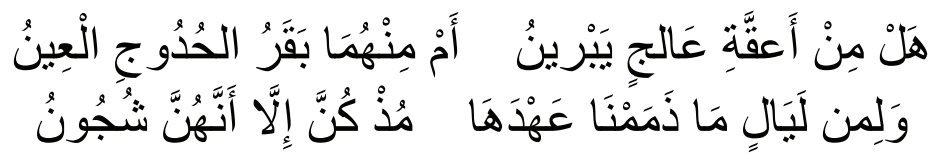

He also praised his leader, Jawhar Al- Saqali, when he managed to conquer the city of Fez, saying:

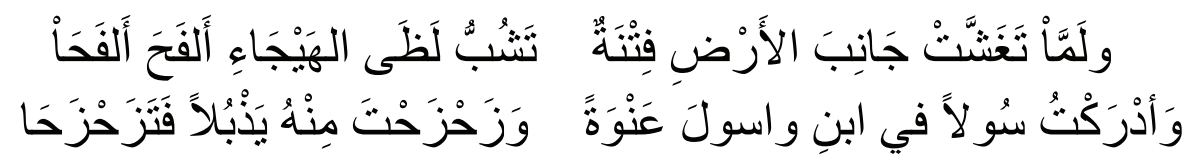

He also used to advocate Ismaili beliefs, from that he said, referring to the necessity of the existence of an infallible Imam at all times:

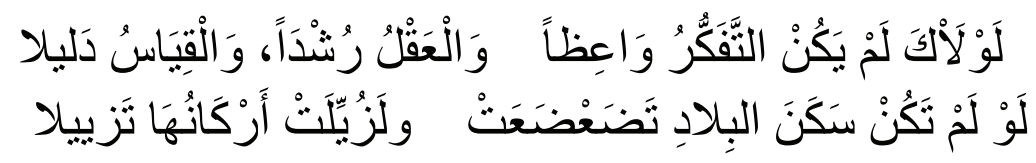

Among the characteristics of his poetry as well is that its meanings are easy and far from complex, free from ambiguity, which are easily and easily revealed to the listener, and the mind receives it as soon as hearing and the slightest contemplation, and this is a feature that almost all his poetry dyes, and what is testified to him by this is his poem which he formulated when Egypt was conquered by Jawhar Al- Saqali, as he said in the beginning:

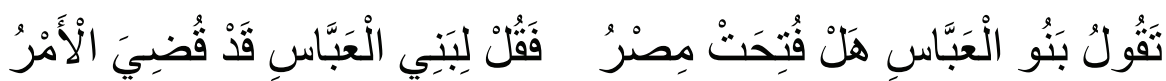

His poetry is characterized by good casting, quality of composition and durability of composition, so that installing the first part is like installing 
the second part and what is evident in this peculiarity from his poetry is his saying:

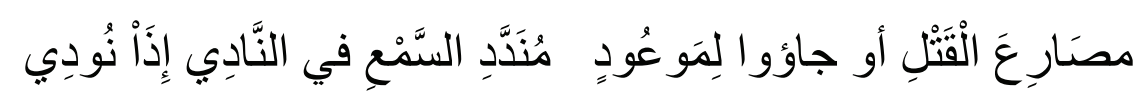

Also his saying:

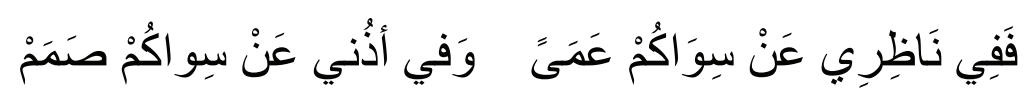

One of the characteristics is that his poetry is characterized by sluggishness and derogatory, it is free from artificiality, far from strange metaphors and unfamiliar similes, and it has been colored with religious motives, as it often talks about religious beliefs, cosmic concepts, or Quranic facts far from the validity and invalidity of the idea that he wants to clarify them. Therefore, we find in many of his poems a quote and an inclusion of the meanings of the verses of the Holy Qur'an, including his saying:

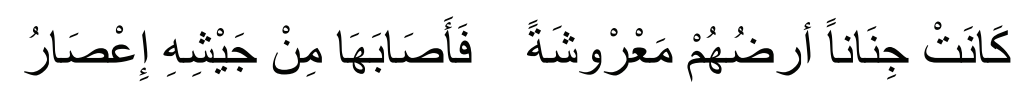

Also his saying:

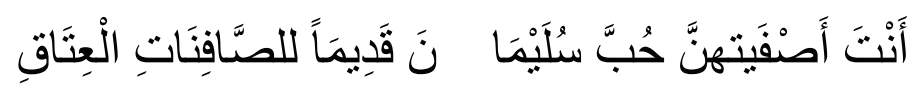

Also his saying:

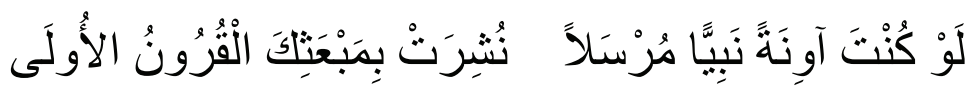

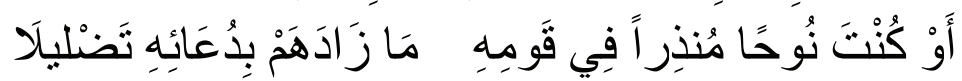

The second topic: the poetic topics that Ibn Hani dealt with in his diwan.

The poetic topics that Ibn Hani talked about in his poetry varied, the most prominent of which is the praise, and among the most prominent of his 
poems in which this purpose appears are those that are known as "Muizzies", which are: "the poems that Ibn Hani sang in al- Muizz Li Din Allah, which have a place in literature, history, politics and society." And, they have huge literary wealth, and great literary glory for Ibn Hani and his art, and these poems that he composed are only in praise of the AlMuizz and his state, and in defense of the Fatimid's right to the caliphate, which are poems that take their high place in Arabic literature. In most of his poems, the poet describes the events of al-Mu'izz with the Romans and his seizure of their country, as the poet spent about four years organizing poetry in it and embedding his emotions towards him and his country. These poems are considered among the most eloquent artistic poems, and amount to about half of his literary heritage, among these poems, the poem in which al-Mu'izz praised the Fatimids and opened it with a flirtatious introduction in which he describes his beloved who went out at night and left him:

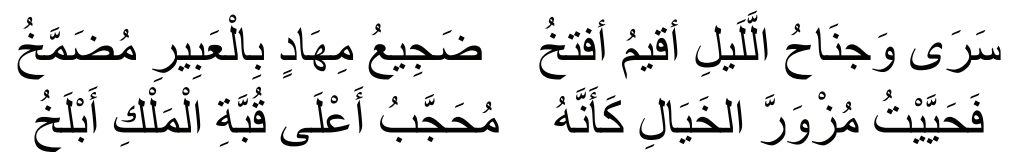

He mixed the words of flirtation with words of praise for the Fatimid alMu'izz.

In another place, we find that he lends to Al-Muizz some controversial divine features that emerged from the Ismaili creed that the poet believes in, which is that there is always a legal imam who is obligated to obey and is supposed to be a successor to the nation and a ruler of the state who enjoys the characteristics and qualifications that other common people lack: 


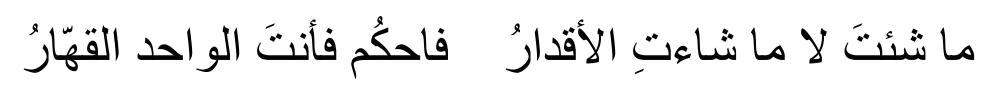

Among the topics that described his art, those doctrinal beliefs, and it seems clear to him, because of his sincerity in his loyalty to the Fatimids of the Ismailis and his devotion to their faith, for which he was tested in Andalusia, this is evidenced by his statement, which depicts the Fatimid belief and the spiritual authority of the Caliph.

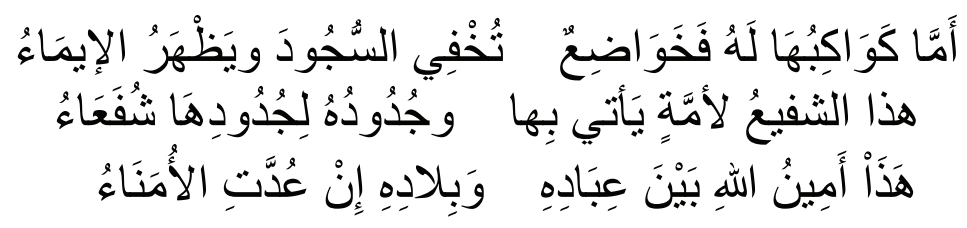

Among the characteristics of Ibn Hani, the description of the horses: When he spoke of the al-Mu'izz's horses, he mentioned that they were generous lineage, and they are quick to run, and they are also very proud:

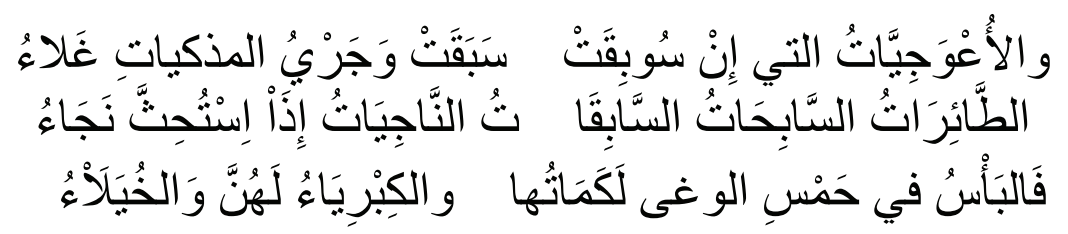

The description of the horses shares the description of the ships. It describes the ships of al-Mu'izz's that fought the battles with the polytheists in many poems, in one of the poems that took place between the Muslims and the Romans, he talks about this sea battle, as he says that these ships are running in the water, lifting their castles and the wind gently pushes them, and that they are unmatched in their good workmanship.

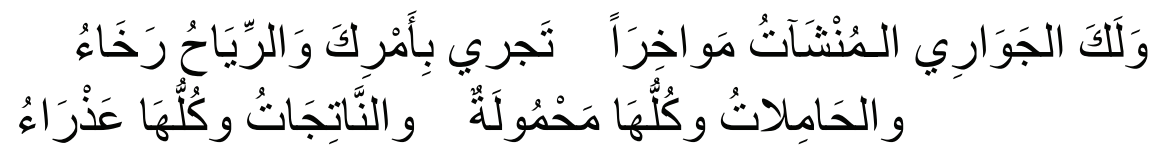


He was also distinguished by the purpose of describing the battles and wars. When Al-Muizz reached the news of the conquest of Egypt by his leader Jawhar, Ibn Hani depicted this conquest and its news and political consequences in an eloquent poem:

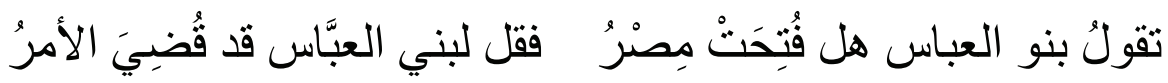

As for the lamentation, his diwan was almost devoid of it, so it was not found that he lamented anyone except two who are not related to him by kinship, namely Ibrahim bin Jaafar, and a young son of Ibn Hani 'he lamented in a poem, and Umm Jaafar lamented two poems, and it was from what he said:

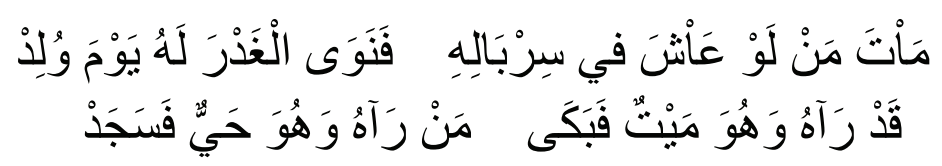

As for spinning, the poetic purpose pursued for this poetic purpose in Ibn Hani's poetry hardly falls on anything but a little, most of it takes the characteristic of poetic stories, their elements and artistic components, including his saying:

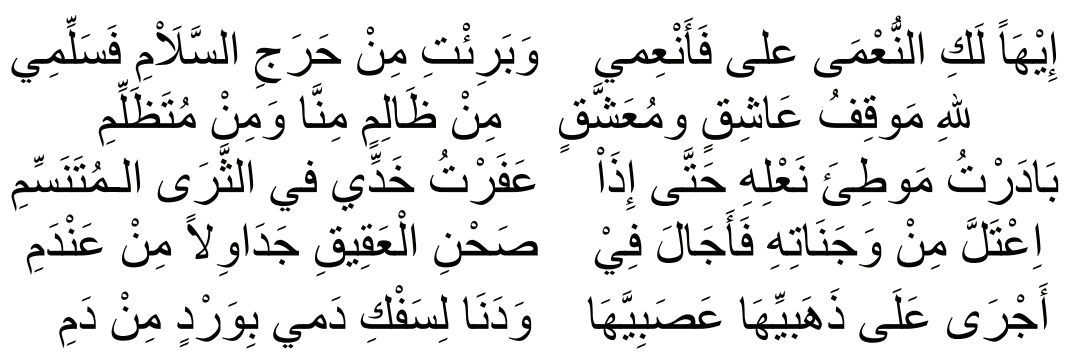

The most correct view is that Ibn Hani Al-Andalusi did not love in his life because we did not find in his poetry the name of a girl he loved, and he mentioned her more than usual as the habit of loving poets. 
Satire was clear in his poetry, especially for the Bani al-Abbas, who are considered the enemies of the Fatimids, which led him to undermine them and mention their faults, including his saying:

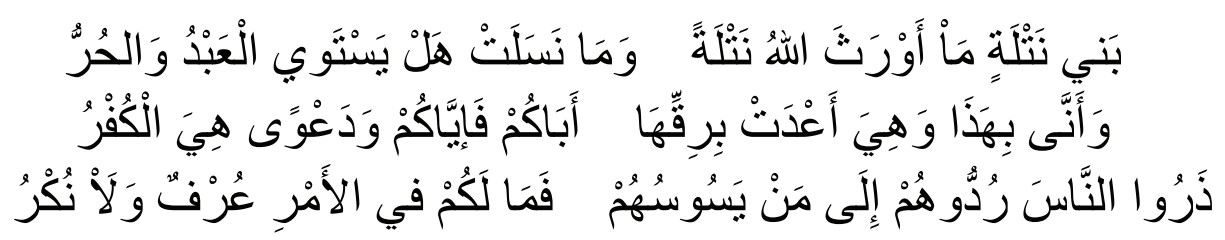

Books on the life and poetry of Ibn Hani, Munir Naji, Abu al-Qasim Muhammad Qari, Ahmad Khalid, Muhammad bin Ali al-Harfy and Ahmad Hassan Bisek independent research.

\section{The third topic: the diwan of Ibn Hani and its commentaries.}

Ibn Hani's poetry was the focus of scholars. Therefore, the number of manuscripts in the important libraries of his divan in the world and in the private libraries of the Ismaili Shi'a scholars in India reached twenty-eight.

The first edition of the Divan was published in Bulaq (1274/1857) with the biography of the poet that Ibn Halikan wrote and explained some words, and a relatively better version of this publication was issued in terms of reading, although it does not give interpretations of the words, in Beirut (1302/1884, 1304 / 1886). And it has different other editions too.

Ibn Hani's divan, the researchers, dealt with the explanation, study and investigation, and among the most important of his explanations:

1) Ibn Hani Al-Andalusi's Divan, Karam Al-Bustani, Beirut House for Printing and Publishing, Beirut, 1980 AD - 1400 AH, and the 
investigator provided an introduction for him, in which he defined Ibn Hani, his upbringing, his belief and his position from the Fatimid state, and his literary stature, which the investigator explained in the footnote, and clarification what its meanings.

2) Illustrating the meanings in the explanation of the poetry of Ibn Hani Al-Andalusi al-Maghribi, corrected, refined and explained - with an introduction quoting several written copies Dr. Zahid Ali, whose number of pages is nearly nine hundred pages, the commentator began by explaining the reason for electing this diwan for printing, as well as He talked about the printed copies of the divan, and that they are three copies, once in Egypt in $1274 \mathrm{AH}$, twice in Beirut, once in $1886 \mathrm{CE}$, and once in $1326 \mathrm{AH}$, then he spoke about the handwritten copies of eighteen copies, thirteen of which are preserved in the libraries of Europe and Egypt, and five copies in India.

Then he mentioned a translation by Ibn Hani, in which he mentioned his birth, lineage, upbringing, and upbringing, also talked about his murder and explained the reason for that, as he spoke about the opinions of literary critics in his poetry, then he mentioned the peculiarities of his poetry, then he mentioned five particulars, then he mentioned the faults of his poetry, as he met between the poetry of Ibn Hani and Al-Mutanabi, then he mentioned the contemporary poets of Ibn Hani who were affected by his poetry, then he talked about Ibn Hani the Younger, who is known as the polite system, concerning the poems, and covered the terminology and doctrines of the Ismaili Shiites. 


\section{CONCLUSION}

Through our progress in this research, we can draw the following conclusions:

- The literary status of Ibn Hani Al-Andalus in his era, until Ibn Khallakan said about him: "there is no one among the (Maghreb) Westerners who is in his class, neither of their earlier nor of their later ones, but rather he is the most famous of them at all, and he is like Al-Mutanabbi in AlMashareqah and they were contemporaries."

- The status of the Fatimid caliph according to Ibn Hani, regardless of the different types and types of that status, some of which were literary, recorded the most wonderful praise poems that Ibn Hani said in praise of al-Muizz, which had an important place among critics and embodied their admiration and pride in them. Further, some of them were historical, as the mourners of Ibn Hani had a major impact on the history of the most important events in the countries of the Maghreb, as well as the political position, especially upon the arrival of the Fatimid mourner, the news of the conquest of Egypt by his leader, Jawhar al- Saqali, Ibn Hani beautifully portrayed this conquest, its news and political results.

- Ibn Hani represents a new trend in the characteristics of poetry, in which he confronts the poetic trend that rebelled against the characteristics of old Arabic poetry. This new trend was conservative on the one hand, and again on the other hand, as he preserved the poetic approach of the poem in terms of language and music, but it is considered as renewing in the meanings and images of poetry. 
- Of Ibn Hani, to this day, there has remained a collection in which his poems were collected alphabetically only. It is not known whether he wrote prose or not. In his collection (divan), which has about four thousand verses, there are mostly praise-type poems, despite their scarcity, and it contains mourning poems and satire as well.

\section{References}

[1.]Al Dayah, Muhammad Radwan, in Andalusian Literature, Dar Al Fikr, Damascus, 2000 AD - 1421 AH.

[2.]Al-Bahbiti, Naguib Muhammad, History of Arabic Poetry until the end of the third century AH, Dar Al-Kutub Al-Masrya Press, Egypt, 1950 $\mathrm{AD}$.

[3.]Al-Hamwi, Shihab al-Din Yaqut bin Abdullah, Dictionary of the Writers, edited by: Ihsan Abbas, Dar Al-Gharb Al-Islami, Beirut, 1993 AD - 1414 AH.

[4.]Ali, Zahid, Explaining the Meanings in Explaining the Divan of Ibn Hani Al Andalusi Al Maghribi, Al Ma'arif Press, Cairo, 1352 AH.

[5.]Al-Maqri, Shihab al-Din Ahmad bin Muhammad, al-Tayyib from Ghosn al-Andalus al-Rutayeb, and its minister, Sanuddin bin alKhatib, was mentioned by: Ihsan Abbas, Dar Sader, Beirut, 1st Edition, 1968 AD.

[6.]Al-Maqrizi, Ahmed bin Ali bin Abdul Qadir, Homilies and consideration by mentioning plans and monuments, Dar Al-Kutub AlIlmiyya, Beirut, 1st Edition, $1418 \mathrm{AH}$

[7.]Al-Zarkali, Khair Al-Din Bin Mahmoud, Al-Alam, House of Science for the Millions, Edition 15, 2002 AD. 
[8.] Amiri, Samira, Bahloul, Noura, the cultural life of the Fatimid state in the Maghreb countries, the graduation note to obtain a master's degree, under the supervision of: Yassin Boudariah, University of Bouira, academic year, 1435-1436 AH, 2014-2015 AD.

[9.]Heikal, Ahmad, Andalusian Literature from the Conquest to the Fall of the Caliphate, Dar Al Maaref, Cairo, 1st Edition, 1985 AD

[10.] Ibn Al-Atheer, Abu Al-Hassan Ali bin Abi Al-Karam Muhammad bin Muhammad, Al-Kamil in History, edited by: Omar Abd Al-Salam Tadmouri, Dar Al-Kitaab Al-Arabi, Beirut, 1st Edition, 1997 AD 1417 AH.

[11.] Ibn Al-Imad Al-Akry, Abdul-Hay bin Ahmed bin Muhammad, Gold Nuggets in News from Gold, edited by: Mahmoud Al-Arna out, Dar Ibn Katheer, Damascus-Beirut, 1st Edition, 1986 AD - 1406 AH.

[12.] Ibn al-Jawzi, Jamal al-Din Abu al-Faraj Abd al-Rahman bin Ali, the regular in the history of nations and kings, investigation by: Muhammad Abd al-Qadir Atta, Mustafa Abd al-Qadir Atta, Dar alKutub al-Ilmiyya, Beirut, 1st Edition, 1992 AD - 1412 AH.

[13.] Ibn Hani Al-Andalusi Diwan, Beirut House for Printing and Publishing, Beirut, 1980 AD - 1400 AH.

[14.] Ibn Khallikan, Abu al-Abbas Shams al-Din Ahmad bin Muhammad, and the deaths of the notables, Dar Sader, Beirut.

[15.] Ibn Masum, Sadr al-Din al-Madani, Ali bin Ahmed, The Predecessors of the Age in the Beauties of the Poets in all of Egypt, Al-Khanji Library, Egypt, 1906 AD - 1324 AH. 
[16.] Imad al-Din, Idris, History of the Fatimid Caliphs, the special section of the book Ayyun al-Akhbar, edited by: Muhammad alYa'lawi, Dar al-Gharb al-Islami, Beirut

[17.] Journal of the College of Islamic Education for Educational and Human Sciences, University of Babylon, Issue 19, February, 2015 AD.

[18.] Kahaleh, Omar Bin Reda, Authors' Lexicon, Al-Muthanna Library, Beirut, House of Revival of Arab Heritage, Beirut.

[19.] Khafaji, Muhammad Abdel Moneim, Andalusian Literature, Evolution and Renewal, Dar Al-Jeel, Beirut, 1st Edition, 1992 AD $1412 \mathrm{AH}$.

[20.] Khafaji, Muhammad Abdel Moneim, The Story of Literature in Andalusia, Knowledge Library, Beirut.

[21.] M. Faruk Toprak, İbn Hânî , DİA, XX, 27-29, İstanbul 1999

[22.] Mustafa Aydın, İbn Hânî el- Endülüsî, Endülüslü Ünlü Şair (Yayınlanmamış makale çalışması)

[23.] Rashid, Nazem, Arabic Literature in the Abbasid Era, Directorate of Dar Al Kutub for Printing and Publishing, University of Mosul, 1989 AD - 1410 AH.

[24.] Safadi, Salah al-Din Khalil bin Aybak, al-Wafi of the deaths, edited by: Ahmad al-Arnaout and Turki Mustafa, House of Revival of Arab Heritage, Beirut, 2000 AD - 1420 AH. 